Journal of Architectural Research and Education (JARE)

Vol. 1 (2) 75-84

@ Mutiawati Mandaka, Adi Sasmito. 2019

\title{
Analysis of the Existence of Signage in Batik Lasem Tourism Village
}

\author{
Mutiawati Mandaka ${ }^{1}$, Adi Sasmito² \\ 1,2 Architecture, FT Universitas Pandanaran, Semarang, Indonesia \\ 1,2 Jln. Banjarsari Barat No 1 Pedalangan, Banyumanik, Semarang, Indonesia \\ Corresponding Author: mutia.mandaka@unpand.ac.id \\ andisasmito@gmail.com
}

Received: 5 Oktober 2019
Revised: 15 November 2019
Article History:

Accepted: 20 Desember Available online: 31 Desember 2019
2019

\begin{abstract}
Research on the analysis of the presence of signage in the Lasem Batik Tourism Village aims to identify signage, activities and visual areas of the Lasem written batik area, identify visual forming factors in the Lasem written batik area and get an analysis of the presence of signage in the Lasem batik tourism village area and provide recommendations on the results of the analysis so that they can provide a reference and guide for local governments/managers in carrying out the stages of developing a new tourist attraction vehicle in Rembang district.

This study uses quantitative rationalistic methods, using regression analysis techniques to look for significant signage influence. Stratified random sampling is used to achieve objectivity. The population used as respondents are people with an educational background in architecture, the general public and residents who live there every day. Furthermore, the number of samples taken proportionally, while the sample area is determined using the area sampling technique. This method was taken in accordance with the purpose of the study to analyze the presence of signage in the Lasem has written batik tourism village area. Based on the findings it can be concluded that the presence of signage in commercial buildings/showrooms has a significant positive effect on the visual aesthetic of Lasem Batik Tourism Village.
\end{abstract}

Keyword: Signage, Visual Aesthetics, Lasem Batik Tourism Village

\section{Introduction}

The Tourism Village, located in Lasem Subdistrict, Rembang Regency, is part of a management system for the work of written batik originating from ancestral heritage which has high historical and artistic values handed down from generation to generation. The production of Lasem batik has its own uniqueness. The current situation shows that the impression of the product (product image) of Lasem batik is still quite strong, especially among ancient batik collectors and other consumers. The history of Lasem written batik is strong and has its own characteristics making batik Lasem for some people feel more special than similar batik. How to make it that still uses the traditional process also makes Lasem batik become more classy and has fairly high competitiveness in the batik market.

This peculiarity makes the production of written batik already marketed in various regions and even outside of Java. The locations of the Batik Write crafters centers in Rembang are 59 crafters in all, but all of them are spread in the locations of Lasem District and Pancur District. Lasem District is spread in the villages of Selopuro Village, Gedongmulyo Village, Karangturi Village, Sumbergirang Village, Soditan Village and Babagan Village. Pancur Subdistrict in Desa Jeruk Village, Pohlandak Village and Karaskepoh Village.

Lasem handmade batik is one of the superior products of Rembang Regency which is derived from the heritage of ancestors who have high historical and artistic values which were handed down from generation to generation. Potential locations in the Lasem Batik Tourism Village area are 
Chinatown and still have original architectural value, as well as other ancient buildings such as the Ancient Mosque on the edge of the highway. The temple, as well as its location, is divided by the Babagan river. Location The area now has a Batik Show Room on the edge of the highway and there are already directions to the batik craft center. Chermayeff (1981) in Mandaka (20015) states that the placement of signage or signage in buildings is related to the condition of the area, so its placement can be a positive or negative impact on the area. Buildings are urban elements and signage or billboards attached to buildings have a major influence on the visual quality of urban areas (Carr, 1973). The tourism village area needs to explore potentials that support the area, as well as clear paths. Besides that, also to preserve, promote and develop Lasem batik, the villages of Babagan and Karasgede are one of the centers of Lasem batik makers.

In an effort to regulate and organize the Batik area, researchers will analyze the presence of signage in several tourist villages in the batik area, so that the function of the region is maintained, namely as a batik tourism village area and tourism development. The development of tourism in the Batik Tourism village area so that regional activities can mutually support one another. Research in this area is an effort to explore the existing potential, as well as making the uniqueness of the tourist village so that the embryo of tourism activities can grow and develop in the district of Lasem.

\section{Problem Identification}

From the description above, the following research problems can be formulated:

1. Changes in the designation of residential land into the Lasem batik tourism village area led to the emergence of signage along the Lasem Batik tourism area.

2. The existence of these signage/signage in the Lasem has written batik tourism area tends to better utilize the economic potential of the region so it is necessary to know whether its presence has had a positive influence on the Lasem Batik tourism village.

\section{The Scope of Research}

The scope of research that becomes the substance of this study are billboards/signage that attaches to buildings and is located in the tourist village area. The Batik tourism village area includes: 1. Babagan Village, Lasem Subdistrict to Ngropoh sub-village, Pancur Village, Pancur Subdistrict.

2. The boundaries of the batik village are Babagan village, Karasgede village, Karaskepoh village, Tuyuhan to Ngropoh hamlet Pancur village. However, in this research area, the only limitation to the research was Babagan Village, Karasgede Village and Karaskepoh Village.

\section{Literature Review}

\section{Urban Design}

Urban design is part of the planning process related to the quality of the city's physical environment as a continuation of urban planning (Shirvani, 1985). Amos Rapoport in Catanese (1986) explains that cities will not emerge suddenly, so there is no possibility of a city revolution (urban revolution) because cities grow gradually in accordance with the culture of their people. The historical background of urban design is divided into two categories, namely self-conscious design (consciousness) and self-conscious design (unconsciousness).

A self-conscious design created by people who consider themselves designers. Their expertise is used to create a comfortable urban environment, with a clear set of ideas or design principles. Unconscious design is created by people, not designers, but has a role in determining the shape of the urban environment, and based on unclear intuition.

\section{Signage}

According to Echols (1975), the sign is a sign, whereas in architecture sign is defined as forms of information and orientation of the city specifically designed as part of eight elements of urban design (Shirvani, 1985). Whereas Rubenstein (1992) defines that signage is visual signs in urban areas that function as architectural means of information or communication. In line with the above, Lynch (1962) states that the sign can function as a tool for orientation for city residents. The same is the case with Sanoff (1991) which says that signage in the use of sign, its existence provides information to people who are passing, walking or driving. Venturi et al. (1987) in signage research in the city of Las Vegas indicates that signage can create an image for a city, the image of Las Vegas: Inclusion and allusion. This is caused by the presence of signage that dominates the city of Las Vegas. Las Vegas without signage is not Las Vegas (Frey, 1999). 
Target and Signage Functions

Signage has two goals, direct and indirect. Direct communication, specifying business identity, location and business goods and services offered. The signage has direct links with the building and the local environment. While signage that has no connection with activities in the building or the local environment is indirect communication

As one of the elements of urban design and markers for an area or city, signage has a variety of functions. The importance of the signage planning function was stated by Rubenstein (1992) in his book Pedestrian Mall, Streetscape and Urban Space. There are four main functions of signage that make signage an important element in the city:
1. Mall identity
2. Traffic signs
3. Commercial identity
4. Information signs

\section{Type of Signage}

From its type, the signs can be divided into:

1. Identity

2. Building Names

3. Circulation Guidelines

4. Commercial

5. Directions to other locations and facilities

6. Information

7. Location Signage

Location (placement) signage by designation is divided into zones (Shirvani, 1985):
1. Pedestrian Zone (Identification)
2. Traffic zone
3. The advertising zone

\section{Signage Classification}
1. Freestanding Sign
2. Wall Sign
3. Roof Signs
4. Suspended Sign
5. Projecting Sign
6. Marque Signs
7. Window/Door Signs
8. Billboard
9. Snipe Signs
10. Parked Vehicles with Signs

\section{Visual Characteristic}

The visual character of an area is shown by the physical quality formed by the interrelation between visual elements in the city landscape, consisting of:
1. Domination
2. Diversity
3. Continuity
4. Intactness
5. Unity
6. Sequence
7. Vividness
8. Uniqueness

\section{Aesthetics}

The elements to analyze the aesthetic quality of urban design according to Moughtin (1992) consist of cohesiveness, balance, proportion, scale, contrast, and harmony and rhythm.

\section{Factors of Aesthetics}

Aesthetic factors consist of: 
1. Unity

2. Proportion

3. Scale

4. Balance

5. Rhythm

6. Color

\section{Serial Vision}

In seeing the visual system of the area according to Cullen in Zand (1999), there are three aspects that must be considered, namely orientation, place and content.

\section{Orientation}

A city or part of the city cannot be seen in just one point, but through a process of observation in motion. Cullen uses the term optics in the process, which is divided into two groups:

1. The existing view (existing view), focused on one area only.

2. The emerging view, focus on the relationship between one region and another.

Usually, people do this without special knowledge or attention, and they see unconsciously what is and is happening visually if it moves from one place to another. However, in his unconsciousness, people always receive various information from their environment that will influence their situation, both through social and architectural factors (Zahnd, 1999).

\section{Position}

Cullen (1962) illustrates that people always need a feeling of their position in an environment, where they are, both consciously and unconsciously. However, in this aspect people's feelings about the identity of the place have two sides: I am here, not there. The phrase is very important for one's feelings because without sensitivity to there does not appear sensitivity to here and vice versa. Between there and here in urban design depends on the way of separation or transportation. Feelings of people's position are very dependent on two factors, namely the level of the limit (enclosure) and the level of protection (exposure). With a feeling of position, people will feel they are on the edge, inside, or outside an area of the city.

\section{Content}

People's feelings about the place are also influenced by what is there. In this aspect the feeling of identity has two aspects, namely: This is this, not that! This means that without sensitivity to this there is no sensitivity to that and vice versa. People distinguish and connect materials through appearance, color, pattern, nature, scale, and others. While people's feelings about a place depend on two factors, namely conformity and on the level of creativity. This can be interpreted if a place is realized in the same way, resulting in a sense of boredom. However, if the manifestations are in very different ways, chaos will arise (Zahnd, 1999).

\section{Research Methodology}

\section{Research Approach}

The approach in the analysis of this study uses a method based on research objectives that emphasize signage analysis of the visual aesthetics of the Lasem Batik village tourism village area which is then qualitatively (interpreted). Namely as follows:

Quantitative Rationalistic Method, to obtain facts of the presence of signage in the batik tourist area Write Lasem descriptively, in-depth and in detail.

\section{Determine Research Variables}

The research variables are obtained from the results of the literature review and factual conditions in the field that affect the research object as follows:

1. In analyzing the presence of signage to the visual aesthetics of Lasem batik tourism village, the signage is determined as an independent variable and visual aesthetic as the dependent variable.

2. From these variables then elaborated into variable indicators that are used as a reference in compiling a survey questionnaire as follows: 
a. Influence variables (independent variables), namely:

Signage (billboards, building signs, information boards found in the Lasem written batik tourism village area.

b. Indicators / variables affected (dependent variables) include:

Cohesiveness, Proportion, Scale, Balance, Rhythm, Color and Serial Vision

Furthermore, the indicators of these variables are arranged in questions to tap respondents' perceptions in the five categories of measurement values (assumptions using the Likert scale / ordinal scale of the answers strongly agree, agree, doubt, disagree and strongly disagree with the question posed.

\section{Research Stages}

The stages of this visual research are:

1. Identification of signage, activity and visual area of Lasem written batik tourism area

2. Identification of visual forming factors in Lasem has written batik tourism village

3. Analyzing the presence of signage found in the Lasem written batik tourist area

\section{Data Collection Technique}

Data was collected using a questionnaire with questions arranged based on indicators and benchmarks. The type of data and data collection carried out consists of two forms, namely:

a. Direct data collection (primary data)

b. Indirect data collection (secondary data)

In determining the research sample used two sampling techniques, namely: a. Stratified Random Sampling, used to determine respondents.

The respondents consisted of 3 groups:

- Respondents with an educational background in Architecture

- General public

- Occupants

Data Respondent :

\begin{tabular}{|c|c|c|}
\hline Stratum & Specifications & $\begin{array}{c}\text { Number of } \\
\text { Respondents }\end{array}$ \\
\hline A & A respondent with an educational background \\
Architect & 10 \\
\hline B & General Public & 10 \\
\hline C & $\begin{array}{c}\text { Residents, who are around the Batik Lasem } \\
\text { Tourism Village }\end{array}$ & 10 \\
\hline
\end{tabular}

Table 1. Determination of the number of Respondents

(source: data processed, 2019)

a. Area Sampling, penentuan lokasi atau kawasan penelitian yaitu dibagi menjadi 3 area : Desa Babagan, Desa Karasgede, dan Desa Karaskepoh.

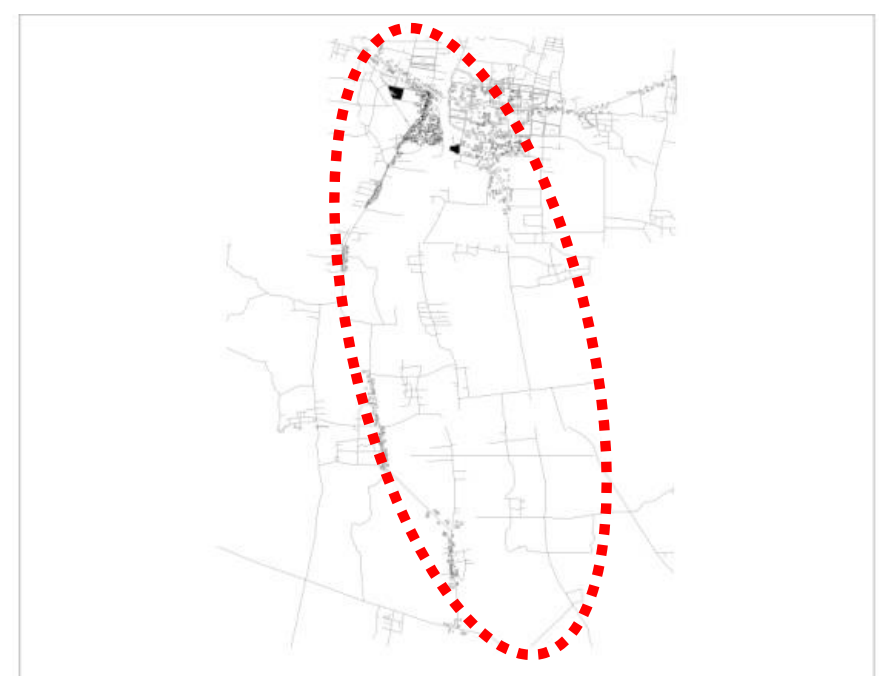

Figure 1. Sampling area location map Batik Tourism Village in Lasem (Babagan Village, Karasgede Village, and Karaskepoh Village) 


\section{Teknik Analisis Data}

The analysis technique in this study began by collecting respondents' assessment data in the field. To determine the validity of the data is done by testing the validity of the "r" indicator (Product Moment Pearson), using SPSS with correlation techniques. The results of the analysis in the form of data obtained are quite a lot so that the next data is reduced and grouped by making tables in accordance with the specified strata. From this process, an assessment was obtained from each group of respondents who then made diagrams so that the comparison of the ratings of each respondent became clear. From the results of the grouping will then produce a conclusion and recommendations regarding the presence of signage in the Lasem handmade batik tourism village.

\section{Result And Discussion}

\section{Research Area}

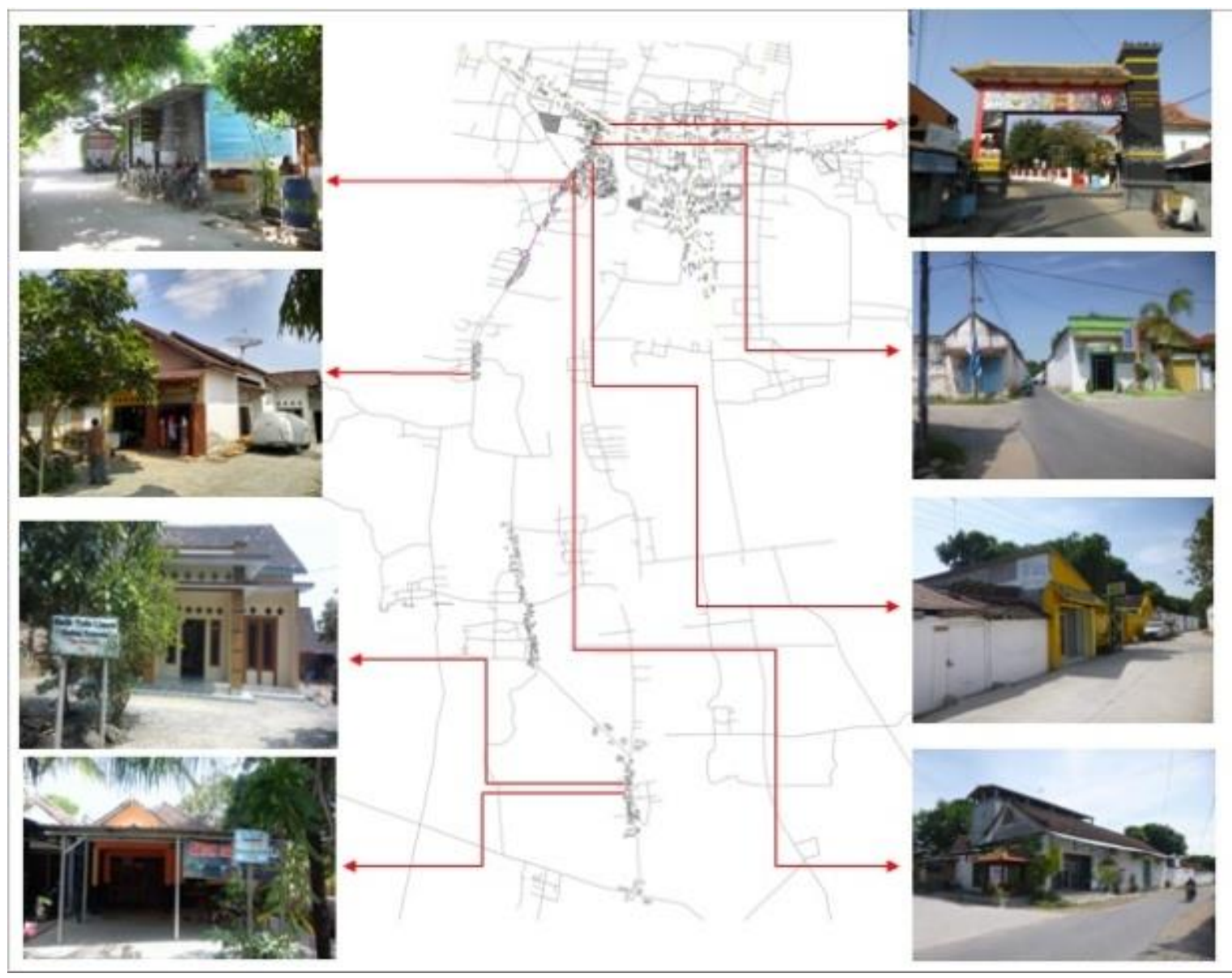

Figure 2. Location of signage in the Tourism Village Batik Tulis Lasem Source: field survey, 2019

From the analysis conducted in the field, it was found that the influence of signage on showroom buildings on the visual aesthetics of Lasem written batik tourism village is as follows:

1. Based on the results of the test of the validity of signage variables on visual aesthetics states that these variables are valid with a confidence level of $90 \%$. The results of the validity test turned out to be sig numbers smaller than 0.01 and the signage variables as well as visual aesthetics were declared valid so that they could be used to look for the influence of signage on visual aesthetics 


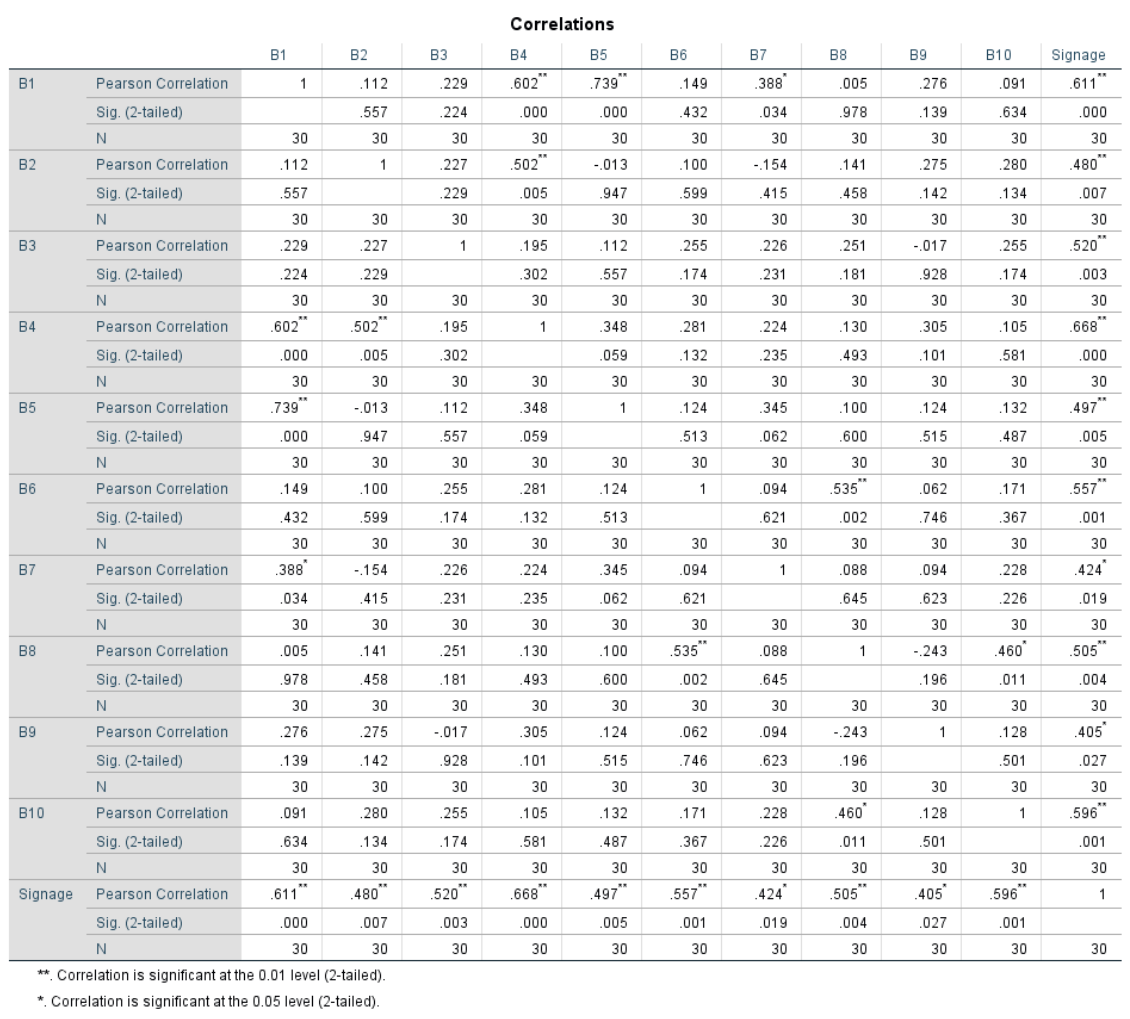

Tabel 2. Validity Tes Results from Variable signage on visual aesthetics Source: processed data, 2019

1. From the regression test results in each group of respondents turned out to produce a positive value which means there is an influence of signage on the visual aesthetics of the corridor, with the following assessment:

a. For respondents, Architects assess the average signage (with a total of 10 data) is 408.00 with a standard deviation of 53.083. While the value for visual aesthetics alone (with a total of 10 data) is 974.00 with a standard deviation of 154.503 . The magnitude of the relationship between variables is quite close $(0.768)$ and the direction of the positive relationship with a confidence level approaching $100 \%$. Figures $r$ square 0.538 , which means $53.8 \%$ of visual aesthetics can be explained by signage variables while the remaining $46.2 \%$ is explained by other factors. Thus it can be seen in diagram 1 of the regression equation for Architect respondents $\mathrm{y}=62.114+2.235 \mathrm{x}$, where $\mathrm{y}=$ aesthetics and $\mathrm{x}=$ signage.

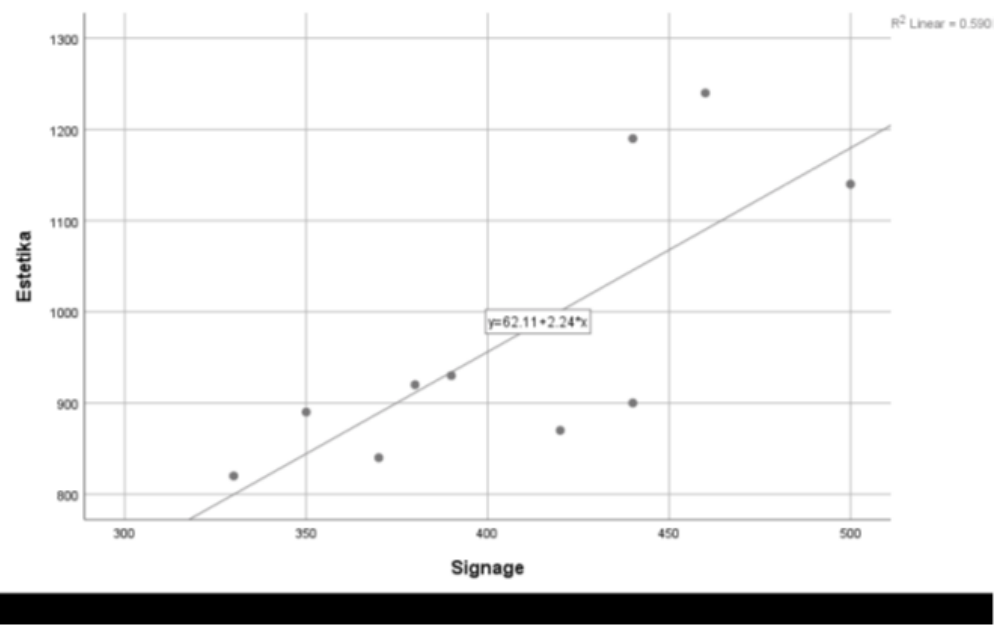

Diagram 1. Graphic Effect of Signage on Visual Aesthetics of Tourism Villages in terms of the views of respondents Architects.

Source : processed data, 2019 
b. For general public respondents, the average signage (with a total of 10 data) is 406.00 with a standard deviation of 52.111. While the value for the visual aesthetic alone (with a total of 10 data) is 972.00 with a standard deviation of 148,309 . The magnitude of the relationship between variables is quite close (0.799) and the direction of the positive relationship with a confidence level approaching $100 \%$. Figures $r$ square 0.638 which means 63.8 visual aesthetics can be explained by signage variables while the remaining $36.2 \%$ is explained by other factors. Thus it can be seen in diagram 2 of the regression equation for general public respondents $y=48,699$ $+2,274 x$, where $y=$ visual aesthetics and $x=$ signage.

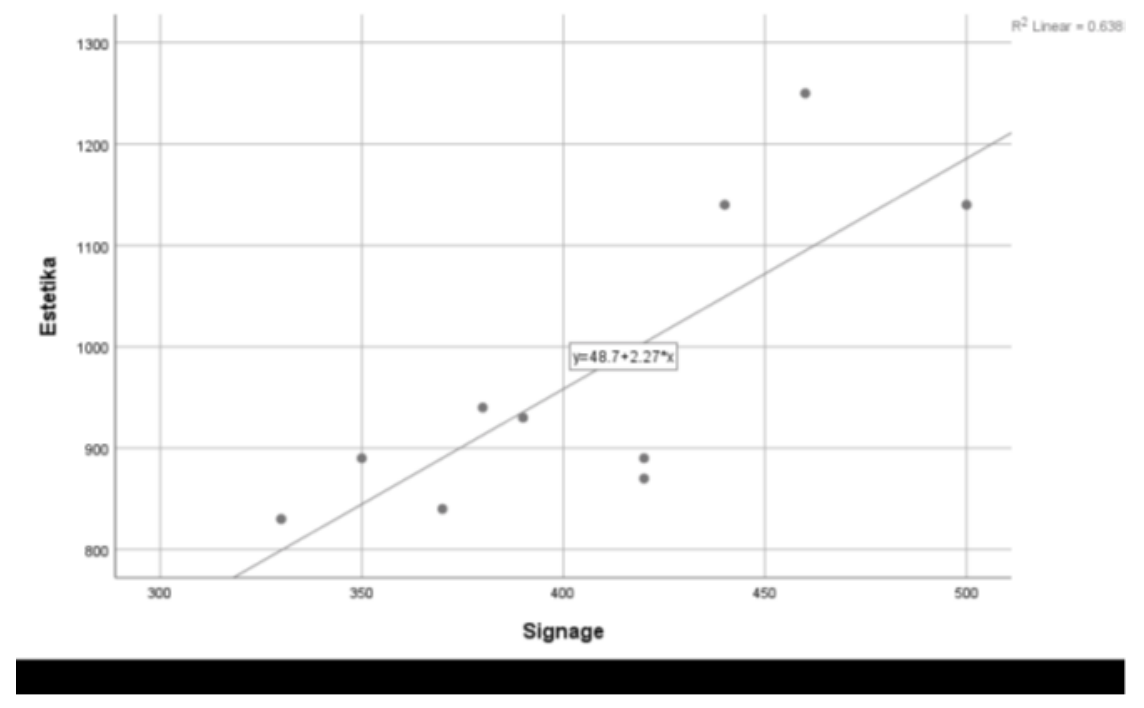

Diagram 2. The graphic effect of signage on Visual Aesthetic of Tourist villages in terms of the views of respondents in the general community.

Source: processed data, 2019

C. For occupant respondents, the average signage (with a total of 10) is 406.00 with a standard deviation of 52.111. While the value for the visual aesthetic alone (with a total of 10 data) is 993.00 with a standard deviation of 156,564 . The magnitude of the relationship between the variables 0.782 and the direction of a positive relationship with the level of confidence approaching $99.9 \%$. The $r$ square figure is 0.612 which means $61.2 \%$ of visual aesthetics can be explained by signage variables while the remaining $38.8 \%$ is explained by other factors. Thus it can be seen in diagram 3 the regression equation for resident respondents $y=39,133+$ $2,349 x$, where $y=$ visual aesthetics and $x=$ signage

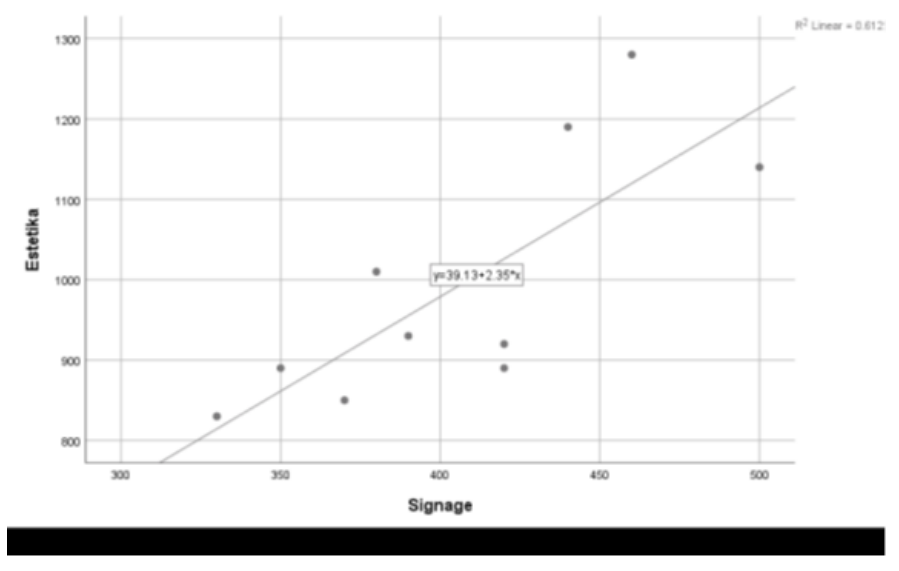

Diagram 3. The graphic effect of signage on Visual Aesthetic of tourist villages in terms of the views of resident respondents

Source: proceed data, 2019

82 | Mutiawati Mandaka, Adi Sasmito 
The line in diagram 3 shows the upward direction which means that there is an influence of signage on the visual aesthetics of the batik tourism village (positive $\rightarrow$ the direction of the line goes up from the bottom up). With a note, if the signage in the batik tourism village is good, it can improve the visual aesthetic quality of the batik tourism village. Whereas if the signage in the batik tourism village is bad, it will worsen the visual aesthetic quality of the batik tourism village.

2. The results of data processing obtained from the questionnaire distributed to the respondents resulted that the average of all respondents view that the signage in the showroom buildings of batik tourism village is good with a percentage of $50 \%$ architect's views, $50 \%$ the views of the general public and $50 \%$ of occupant views. With an assessment of visual aesthetic factors such as cohesiveness, proportion, balance, scale, rhythm, color and serial vision of the respondents (both architects, general public and residents) consider that:

a. Unity signage in the Lasem written batik tourism village is not very good ( $70 \%$ of respondents' views of architects, $50 \%$ of views of the general public and residents).

b. The proportion of signage is good according to the views of architects $60 \%$, views of the general public and residents $50 \%$.

c. Signage scale is good, with the views of $60 \%$ of architects and occupants and $50 \%$ of respondents from the general public.

d. The balance between signage has also been good, architectural respondents looked at $60 \%$, general public respondents looked at $70 \%$ and occupants looked good at $50 \%$.

e. The rhythm (the rhythm of the signage in the showroom buildings) is good, the number of architects and occupant respondents who stated good each by $70 \%$ and the general public respondent's rate good $60 \%$.

$\mathrm{f}$. The color of the signage in the showroom building is already good, according to the responsiveness of architects and occupants by $50 \%$ and the general public respondents view the good $60 \%$.

g. Serial Vision according to the respondents is good, it can be seen in the responses of respondents, architects, the general public and residents by $80 \%$ rated good.

3. Based on the graphical analysis of serial vision from the entrance to the tourist village, there are several important points, namely, the movement starts from the gate with additional canting accents that strengthen the location of the written batik tourism village. The scenery along the path of the batik tourist village looks flat or flat so that the placement of signage seems rather monotonous. There are still a lot of trees, especially in the Karasgede and Karaskepoh villages so that it gives a different color and also provides a refreshing sight. At the end of the series vision journey at the written batik tourism village, there is a village boundary gate that marks the end of the written batik tourism village of Lasem.

\section{Result}

Based on the analysis that has been done, there are two things that can be concluded, namely the first signage in the tourist village of Lasem written batik has a significant positive effect on visual aesthetics. Both of this signage can affect the serial vision in the batik tourism village of Lasem. The things that cause these positive effects include:

1. The dominance of the signage function in the Lasem written batik tourism village is more dominant as a commercial identity and directions to locations.

2. The distribution of signage is uneven but still quite regular.

3. The factors causing the aesthetic quality of the Lasem handmade batik tourism village to increase are:

a. Unity formed unity between the elements of the tourist village lane.

b. Proportion, the relationship between elements and the building as a whole has become a visually integrated relationship.

c. Rhythm, rhythm in the Lasem batik tourism village does not seem monotonous.

d. Scale, the comparison between signage and space is quite balanced.

e. Color, for a combination of colors on the signage, is quite regular.

f. Serial Vision, there are views including the focal point, the entrance gate that can be used as an eye-catcher at the beginning of entering the Lasem written batik tourism village. Punctuation (area gate which is included in the freestanding sign (pole sign) emphasizes the transition between Babagan Village to Karasgede and Karaskepoh Villages. Publicity 
(announcement/advertence) is visible on the building wall. This occurred in the Lasem batik tourism village as seen in the placement of signage on the building The plants on the right and left of the road function as conditioning of a brightly dominated environment so as to form a certain rhythm and reduce the monotonous impression which all support the creation of serial vision in the village Lasem handmade batik tourism.

\section{References}

Carr, Stephen, 1973, City, Sign, and Light. a Policy Study, MIT Press, Cambridge.

Catanese, Antoni J. Snyder, James C. Susangko, 1986, Pengantar Perencanaan Kota, Penerbit Erlangga, Jakarta.

Cullen, Gordon, 1962, The Concise of Townscape, Van Nostrand Reinhold Company, New York. Echols, John M. dan Shadily, Hasan. Kamus Inggris Indonesia, Penerbit PT. Gramedia, Jakarta.

Frey, Hildebrand, 1999, Designing the City, Toward a more sustainable Urban Forms, E \& FN Spon, London.

Lynch, Kevin. 1969, The Image Of The City, The MIT Press, Cambridge.

Mandaka, Mutiawati, "Estetika Visual Koridor Pada Bangunan-Bangunan Komersil di Jalan Pandanaran Semarang". Neo Teknika Volume 1, No 2 (2015)

Moughtin, Cliff, 1992, Urban Design: Street and Square, Department of Architecture and Planning University of Nottingham.

Rubenstein, Harvey M, 1992, Pedestrian Malls, Streetscape and Urban Spaces, John Wiley \& Sons, Canada.

Sanoff, Henry, 1991, Visual Research Methods in Design, Van Nostrand Company Inc, New York. Shirvani Hamid, 1985, The Urban Design Process, Van Nostrand Reinhold Company New York. 